\title{
Properties of Sandcrete Block Produced with Coconut Husk as Partial Replacement of Sand
}

\author{
Ubong Williams Robert ${ }^{1}$, Sunday Edet Etuk ${ }^{2}$, Okechukwu Ebuka Agbasi ${ }^{*}$,, Sylvester Andrew Ekong ${ }^{1}$
}

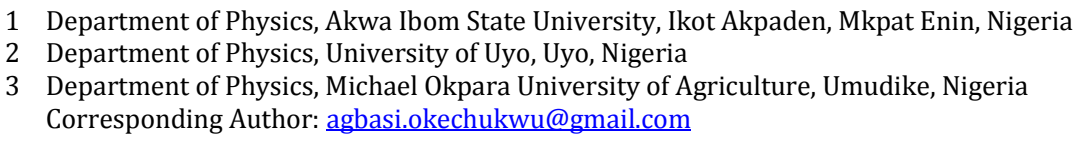

Received: 20-06-2020

Accepted: 19-08-2020

\begin{abstract}
Sandcrete block is the most popular building material in construction industry. However, with the high and increasing cost of building materials experienced nowadays, it has been difficult to achieve affordable housing especially in developing countries. Also, significant dredging of sand for block production and the large amount of coconut husk thrown away as waste have increased the level of concern due to their adverse effect on environment. This work, therefore, sought to produce solid core sandcrete blocks in which sand component is partially replaced with coconut husk and investigate the suitability of using such blocks for building designs. The block samples produced using untreated and also treated coconut husks at various levels of sand replacement were subjected to bulk density, water absorption and compressive strength tests at 7 days and 28 days of curing. It was found that sand replacement with $20 \%$ of untreated coconut husk or $30 \%$ of treated coconut husk could yield a solid core sandcrete block suitable for non-load bearing walls of satisfactory performance. Since coconut husk is cheaply available, sustainable, and recyclable, utilising such promising material in this case can enhance production of costeffective and optimally performing sandcrete blocks for building purposes. This will in turn help to boost the development of housing, minimise loss of agricultural lands, and reduce environmental pollution level, and so on.
\end{abstract}

Key words: Alkalisation; Bulk Density; Compressive Strength; Curing; Water Absorption.

\section{Introduction}

In recent decades, the drive for economic diversification has resulted in greater emphasis on coconut (cocos nucifera) production, especially, in developing countries. Report by Burton (2018), shows that Indonesia is the largest global producer of coconut with 18,300,000 tons, followed by Philippines (15,353,200 tons) and then India (11,900,000 tons). Also, Vanguard newspaper report published on October 17, 2019 had it that Nigeria produced 364,000 metric tons of coconut yearly across 22 states out of which Lagos State contributed the highest amount being 257,000 metric tons. For inculcating all the resources required by man for his survival, coconut is regarded as a must-grown tree. Several benefits that can be derived from coconut include, among others, the use of its trunk for interior building insulation (Etuk et al., 2005) and application of the water from its fruit (coconut water) for health purposes (Prades et al., 1998; Campbell-Falck et al., 2000; Harini, 2010). Notably, coconut tree is a member of palm family called Arecaceae and is known to produce between 30 and 75 fruits annually if planted on a fertile soil. Each coconut fruit yields $40 \%$ husks containing $30 \%$ fibre with dust making up the rest. Chemically, the husks consist of cellulose, lignin, pyroligneous acid, gas, charcoal, tar, tannin, and potassium (Zafar, 2020) and they encompass $80 \%$ to $85 \%$ of the weight of coconut fruit with very high content of lignin (Bolivar-Telleria et al., 2018). Due to the fact that priority is given to the economic and medicinal values of coconut fruits, less value is usually placed on the husks. As such, the husks are simply thrown away as waste. This practice is dangerous as a large 
amount of the waste sent can reach water table and impose a great environmental risk during decomposition. There is, therefore, need to consider recycling such wastes into value-added products for use by man.

One of the basic needs of humans is an affordable housing that has aesthetic value and durability. Nowadays, various grades of materials can be used to build a house. In the construction industry, a mixture of sand, cement, and water in prescribed quantities yields sandcrete block, which as remarked by Ojo (2015), is the most popular building material. Research reports have shown that in Nigeria, over $90 \%$ of walling units in houses and even physical infrastructure are constructed using sandcrete blocks (Baiden and Tuuli, 2004; Oladeji and Awos, 2013). The use of sandcrete blocks for non-load bearing and partition walls helps to control moisture infiltration and wind action, and also provides buildings with aesthetic value. As opined by Omoregie (2012), such uses constitute utility value that is responsible for wide application of sandcrete blocks for building purposes within tropical rainforests where a considerable amount of precipitation and high average temperatures are predominant. Another notable advantage is that sandcrete blocks neither rust nor decay unlike in the case with some other building materials.

The Building Code of Federal Republic of Nigeria (Building code, 2006) stipulates that aesthetics, durability, functionality, character and affordability of housing must be achieved through the application of all materials and components used in construction of buildings. However, such achievement has been hampered in recent times because construction industry relies heavily on conventional building materials. The high and increasing cost of those materials, consequently, cramp the development of housing as well as other infrastructural facilities, thereby hindering compliance with the said Building Code. Also, it has been observed that due to suitability of dredged sand for production of masonry units (Akinpelu and Adekanmbi, 2017), its many uses have led to significant dredging. This has eventually raised environmental concerns over fish depletion, flooding, landslides, losses of agricultural lands as well as damage to buildings. Obviously, the search for alternative and cheaply available materials that can perform effectively, if utilised for building purpose, is inevitable. Attempts so far made in this regard by researchers revealed that substituting high-density polyethylene for sand (Ali et al., 2017), replacing fine aggregates with shredded plastic (Akinyele and Toriola, 2018), and partially replacing cement with eggshell ash (Afolayan et al., 2017) yielded sandcrete blocks with impressive compressive strength. Not only that, even concrete produced with dolomite sand waste was reported to have a set of properties very close to traditional concrete filled quartz sand (Korjakins et al., 2009). In this work, coconut husk is considered for use as partial replacement of sand in the production of solid core sandcrete blocks. The major tests, such as water absorption and compressive strength, required by Nigerian Industrial Standard for verifying the quality of sandcrete blocks (Robert et al., 2019) and also bulk density required by British Standard Institution for the same purpose will be performed. It is hoped that the findings from this work will be useful to researchers, manufacturers/fabricators, practising engineers and designers.

\section{Experimental Perspective}

\subsection{Materials and their description}

Cement (manufactured by Lafarge Africa PLC with certification mark NIS 444 - 1:2018 CEM II BL $32.5 \mathrm{R}$ on the product bag), potable water (free from salts, oil contaminations and suspended particles), white river sand, and brown coconut husks (in lump form) were obtained within Akwa Ibom State, Nigeria and used as basic materials in this research work. In addition to being clean and sharp, the sand was free from dirt, loam, clay and organic matter. It was of specific gravity 2.66 and coefficient of uniformity 2.95. Moreover, the coconut husk contained cellulose (24.72\%), hemicelluloses (12.26\%), lignin (40.13\%), and tannin. 


\section{$2.2 \quad$ Method}

\subsubsection{Materials processing}

The as-received coconut husks were cut into smaller pieces using knife and then processed into two kinds, namely, untreated and treated coconut husks as described elsewhere (Robert et al., 2019). In this case, the chemical modification of the husk particles was done by soaking them in $2 \mathrm{M}$ freshly prepared solution of sodium hydroxide for 18 hours. The sand and processed husks were sun-dried completely (Figure 1 shows the dry forms of the untreated and treated coconut husks used). Then after, five trial runs of sieve analysis were performed for the sand and coconut husks based on the standard procedure outlined in ASTM C136 / 136M, (2019). Also, each of the dried materials was screened using Mesh No. 10 of US sieve and the quantity that passed through the sieve was used for production of solid core sandcrete block samples in this work.

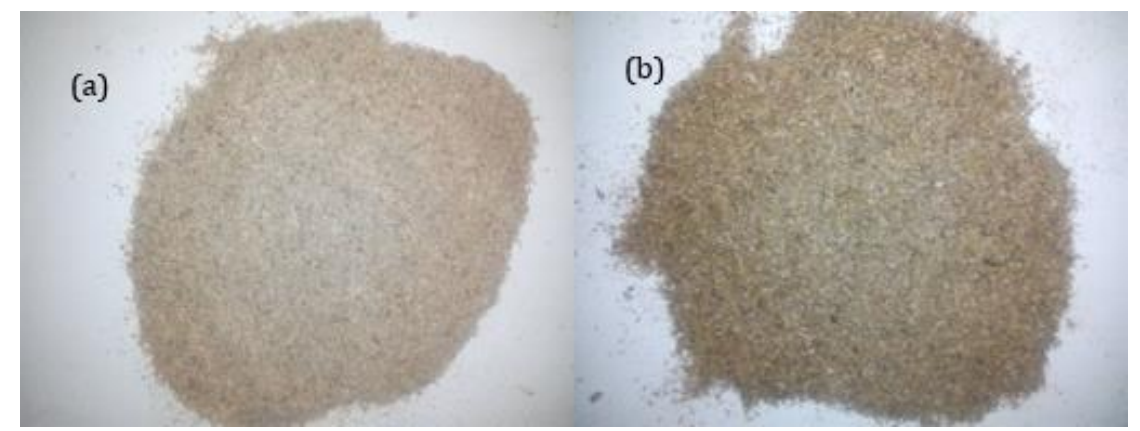

Fig. 1. Dry forms of the (a) untreated coconut husks (b) treated coconut husks

\subsubsection{Production and Testing of the solid core sandcrete block samples}

Under laboratory conditions, the cement was thoroughly mixed with the sand and this was followed by addition of water when an even colour was attained consistently. All the constituents of the mixture were batched by volume method. The cement to sand ratio adopted was $1: 6$ and water -cement ratio of 0.5 was maintained throughout the production process. Also, the resulting mixture was quickly cast in a steel mold of dimensions $100 \mathrm{~mm} \times 100 \mathrm{~mm} \times 100 \mathrm{~mm}$. On reaching half of the depth of the mold, a tamping bar was used to tamp the mixture with 40 strokes over the cross-section of the mold. Then after, more quantity of the mixture was added and tamped as well until the mold was completely filled to its brim. The tamped mixture was demolded as fresh block sample. In this work, such sandcrete blocks produced at $0 \%$ level of sand content replacement with coconut husk served as control samples. Other block samples were similarly produced but at $10 \%, 20 \%, 30 \%$, and $40 \%$ partial replacement levels of the sand content with the untreated coconut husk, and then with the treated coconut husk. After 24 hours, all the block samples produced were kept in a shade and cured by splashing water on them twice daily (morning and evening). At curing ages of 7 days and 28 days, the block samples were tested. For each intended test at a particular curing age, three block samples were produced per formulation and used.

The bulk density of each block sample was calculated as the ratio of mass to bulk volume, expressed mathematically as

$D=\frac{M}{V}$

where $D=$ bulk density, $M=$ mass, and $V=$ bulk volume.

For water absorption test, the mass of the block sample was determined before the block was soaked in cold water at $28^{\circ} \mathrm{C}$ for 24 hours. After removal of the block from the water, its mass was determined and the percentage water absorption, W.A was computed using the formula

$W \cdot A=\left(\frac{M_{s}-M_{d}}{M_{d}}\right) 100 \%$ 
where $M_{d}=$ mass of the block sample before soaking, and $M_{s}=$ mass of the sample after soaking in water.

Compressive strength test was conducted by means of compression testing machine. The data obtained for the cross-sectional area and crushing force of the block sample were used to determine the corresponding compressive strength according to the equation

$C S=\frac{F}{A}$

where $C S=$ compressive strength of the block sample at a particular curing age, $F=$ minimum force required to crush the block sample and $A=$ cross-sectional area of the block. The mean values of the results obtained for each of the tests were determined with their standard error and tabulated.

\section{Results and discussion}

The results of the sieve analysis of the sand and coconut husk used in the production of the block samples are recorded in table 1 . Also, the results of the tests performed on the block samples at different curing periods for various levels of sand partially replaced with coconut husk are presented in table 2 .

The aggregates distribution curves of the sand and coconut husks are illustrated in figure 2. As can be seen, the grading curves for the sand and coconut husks fall within the grading limits for zone one of BS 882 aggregates (BS 882, 1992). This signifies that the sand and coconut husks are well graded and therefore, suitable for use as fine aggregates in sandcrete block production.

It can be seen from table 2 that for a particular sand replacement level, the mean values of bulk density at 28 days of curing are greater than the results obtained at the curing period of 7 days irrespective of whether UCH or TCH is used. This may be attributed to the effect of hydration and it implies that increase in curing duration enhances higher degree of compaction by allowing proper hardening of the blocks. Also, it can be observed that at a particular curing age, block samples containing the TCH have greater mean values of bulk density than their counterparts in which the UCH is used as partial sand replacement material. This is obviously due to alkalisation of raw coconut husk with sodium hydroxide solution to obtain the TCH used in this work. In other words, the alkaline treatment given to raw coconut husk to get the TCH leads to the removal of light and dusty particles that characterise UCH. As such, TCH is denser than UCH and consequently, block samples produced with a particular proportion of the TCH become denser than those with the UCH content of same proportion. With respect to the minimum bulk density of $1500 \mathrm{~kg} \mathrm{~m}^{-3}$ specified in BS2028 (1975) for blocks made with lightweight aggregates, it can be deduced that the least mean values of bulk density obtained in this work exceed the standard lower limit requirement by not less than $5.03 \%$. This means that partial substitution of the sand with $40 \%$ of the UCH or TCH can yield solid core lightweight sandcrete blocks that are suitable for interior building design.

Table 1. Results of sieve analysis of the sand used

\begin{tabular}{|c|c|c|c|c|}
\hline \multirow{2}{*}{$\begin{array}{c}\text { Sieve Size } \\
(\mathrm{mm})\end{array}$} & \multicolumn{4}{|c|}{ Percentage passing (\%) } \\
\cline { 2 - 5 } & Lower Limit & \multicolumn{2}{|c|}{$\begin{array}{c}\text { Upean } \pm \text { Std. error } \\
\text { Limit }\end{array}$} \\
\cline { 2 - 5 } & & Sand & Coconut Husk & 100 \\
\hline \hline 4.750 & 90 & $99.04 \pm 0.09$ & $99.86 \pm 0.07$ & 95 \\
\hline 2.360 & 60 & $87.60 \pm 0.02$ & $87.67 \pm 0.05$ & 70 \\
\hline 1.180 & 30 & $65.73 \pm 0.03$ & $65.80 \pm 0.03$ & 34 \\
\hline 0.600 & 15 & $27.78 \pm 0.02$ & $26.61 \pm 0.05$ & 20 \\
\hline 0.300 & 6 & $17.76 \pm 0.02$ & $14.73 \pm 0.04$ & 10 \\
\hline 0.150 & 1 & $2.28 \pm 0.01$ & $1.51 \pm 0.02$ & 1 \\
\hline 0.075 & 0.1 & $0.44 \pm 0.01$ & $0.28 \pm 0.01$ & \\
\hline
\end{tabular}


Table 2. Results of the tests performed on the block samples

\begin{tabular}{|c|c|c|c|c|c|}
\hline \multirow{2}{*}{$\begin{array}{c}\text { Curing age of } \\
\text { the } \\
\text { samples }\end{array}$} & \multirow{2}{*}{$\begin{array}{c}\text { Sand } \\
\text { replacement } \\
\text { material }\end{array}$} & \multirow{2}{*}{$\begin{array}{l}\text { Level of sand } \\
\text { replaced with } \\
\text { the material } \\
(\%)\end{array}$} & \multicolumn{3}{|c|}{$\begin{array}{l}\text { Mean (with standard error) values of the test } \\
\text { properties }\end{array}$} \\
\hline & & & $\begin{array}{l}\text { Bulk density, } \\
\text { D }\left(\mathrm{kgm}^{-3}\right)\end{array}$ & $\begin{array}{c}\text { Water } \\
\text { absorption, } \\
\text { W.A }(\%)\end{array}$ & $\begin{array}{c}\text { Compressive } \\
\text { strength, } \\
\mathrm{CS}\left(\mathrm{N} / \mathrm{mm}^{2}\right)\end{array}$ \\
\hline \multirow{10}{*}{7 days } & \multirow{5}{*}{$\mathrm{UCH}$} & 0 & $2032.68 \pm 2.39$ & $2.23 \pm 0.07$ & $4.35 \pm 0.03$ \\
\hline & & 10 & $1817.18 \pm 3.12$ & $2.49 \pm 0.04$ & $2.78 \pm 0.03$ \\
\hline & & 20 & $1779.42 \pm 1.98$ & $2.88 \pm 0.01$ & $2.49 \pm 0.03$ \\
\hline & & 30 & $1708.24 \pm 2.38$ & $3.34 \pm 0.04$ & $1.97 \pm 0.01$ \\
\hline & & 40 & $1575.40 \pm 3.75$ & $3.97 \pm 0.07$ & $0.98 \pm 0.03$ \\
\hline & \multirow{5}{*}{$\mathrm{TCH}$} & 0 & $2032.68 \pm 2.39$ & $2.23 \pm 0.07$ & $4.35 \pm 0.03$ \\
\hline & & 10 & $1978.44 \pm 3.88$ & $4.28 \pm 0.02$ & $3.96 \pm 0.05$ \\
\hline & & 20 & $1922.75 \pm 3.42$ & $5.43 \pm 0.05$ & $3.55 \pm 0.04$ \\
\hline & & 30 & $1814.45 \pm 2.74$ & $5.78 \pm 0.03$ & $2.76 \pm 0.03$ \\
\hline & & 40 & $1749.66 \pm 2.94$ & $6.28 \pm 0.04$ & $2.25 \pm 0.03$ \\
\hline \multirow{10}{*}{28 days } & \multirow{5}{*}{$\mathrm{UCH}$} & 0 & $2077.92 \pm 3.62$ & $2.45 \pm 0.03$ & $4.67 \pm 0.05$ \\
\hline & & 10 & $1915.22 \pm 5.09$ & $2.90 \pm 0.04$ & $3.49 \pm 0.04$ \\
\hline & & 20 & $1804.56 \pm 5.04$ & $3.10 \pm 0.03$ & $2.67 \pm 0.04$ \\
\hline & & 30 & $1727.15 \pm 2.90$ & $3.72 \pm 0.04$ & $2.12 \pm 0.03$ \\
\hline & & 40 & $1612.23 \pm 4.02$ & $4.25 \pm 0.04$ & $1.27 \pm 0.05$ \\
\hline & \multirow{5}{*}{$\mathrm{TCH}$} & 0 & $2077.92 \pm 3.62$ & $2.48 \pm 0.03$ & $4.67 \pm 0.05$ \\
\hline & & 10 & $2009.27 \pm 2.12$ & $4.79 \pm 0.03$ & $4.18 \pm 0.03$ \\
\hline & & 20 & $1979.44 \pm 2.62$ & $5.63 \pm 0.04$ & $3.96 \pm 0.04$ \\
\hline & & 30 & $1858.27 \pm 2.93$ & $5.90 \pm 0.05$ & $3.07 \pm 0.04$ \\
\hline & & 40 & $1753.86 \pm 4.28$ & $6.29 \pm 0.05$ & $2.32 \pm 0.04$ \\
\hline
\end{tabular}

UCH = Untreated Coconut Husks; TCH = Treated Coconut Husks

Figure 3 shows that for both curing durations, the bulk density of the block samples decreases with increase in the proportion of either UCH or TCH used.

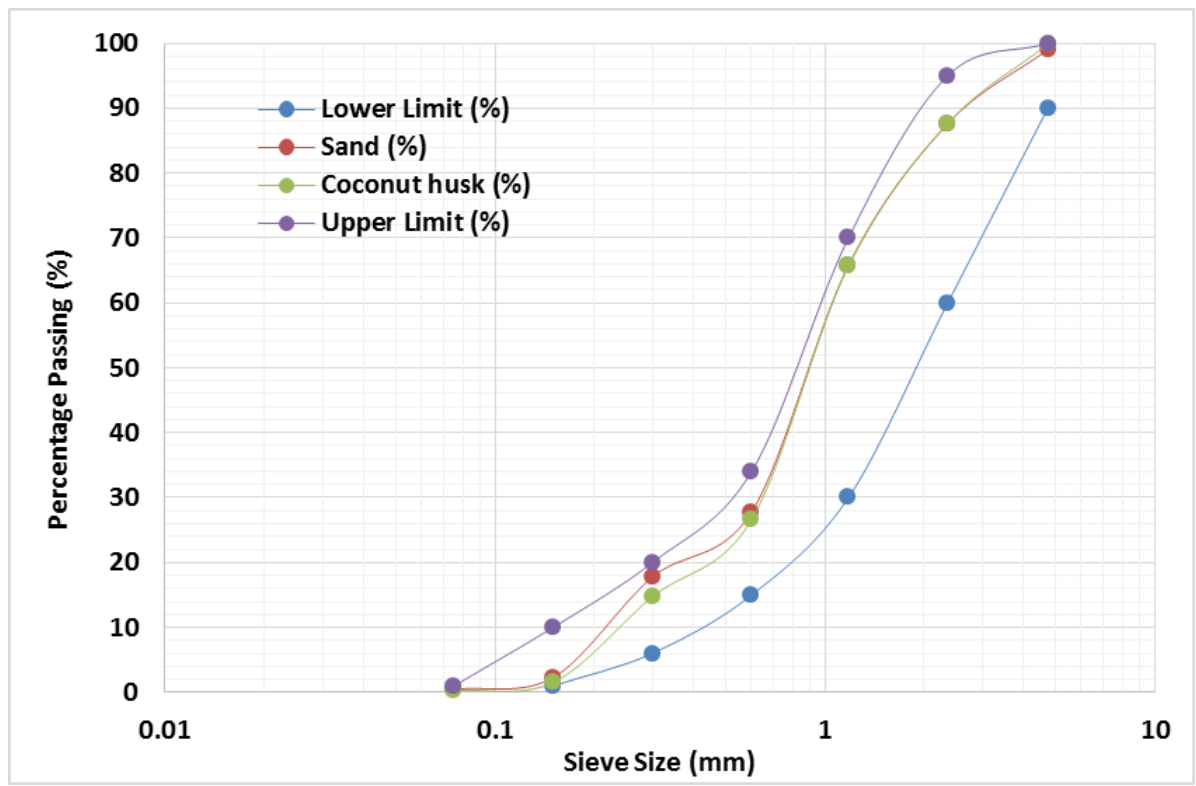

Fig. 2. Plots of sand and coconut husks gradation and limits of zone 1 aggregates to BS 882:1992

This simply portrays the fact that coconut husk is lighter than sand. Thus, the more the added quantity of UCH or TCH is, the lower the bulk density of the block samples becomes. It can be deciphered from the plots that with the use of the UCH, the initial decrease in the mean values of 
the bulk density is more pronounced than in the case of utilising the TCH in the production of the block samples. This observation therefore confirms the verity of the finding that TCH is denser than UCH as asserted above.

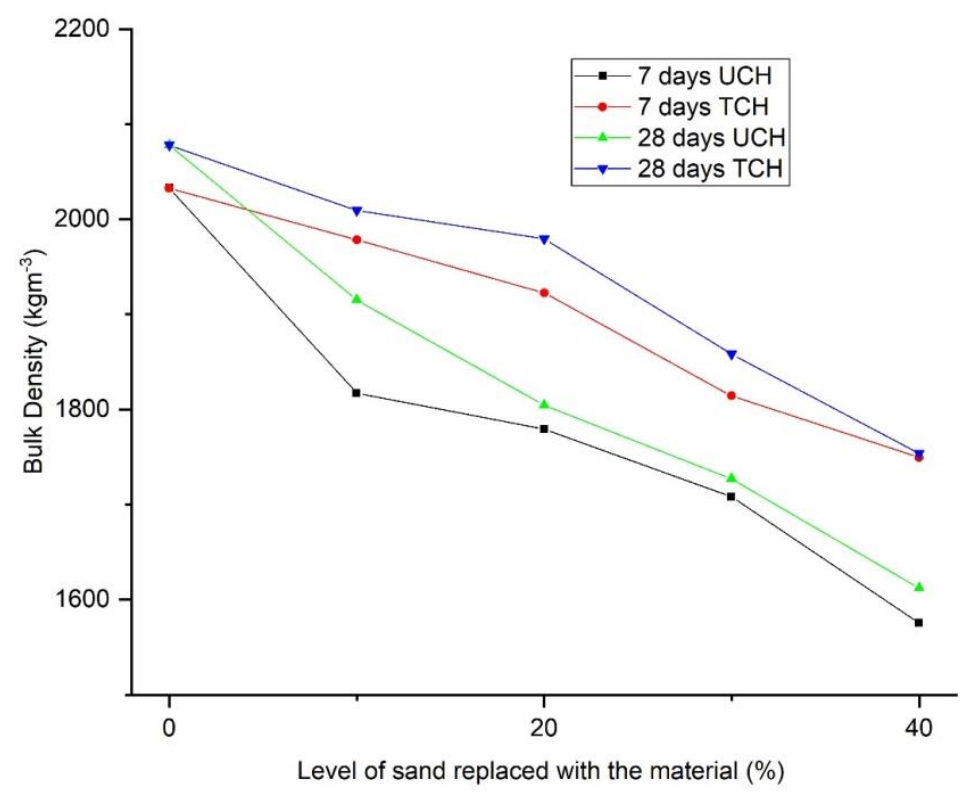

Fig. 3. Variation of bulk density with coconut husk level in the block samples

In the case of water absorption, the results registered in the table show that the mean values of percentage water absorption vary directly with the age of curing for each proportion of sand replaced with the coconut husks. It could be suggested that since hydration proceeds with the presence of evaporable water, increase in age of curing may affect the pore structure of the block samples in such a way that it enhances greater tendency for water permeability from the surface into interior part. From the results presented, it can be observed that there is a marked increase in the mean values of percentage water absorption at a particular curing period of the block samples when sand is partially replaced with the TCH unlike when the UCH of same proportion is used. This clearly indicates that the use of UCH enhances water repellent capability of the block samples whereas sand replacement with TCH does the opposite as a result of its nature. Meanwhile, the cell wall of UCH is covered with highly hydrophobic impurities like lignin, hemicelluloses, tannin, and so on. The removal of a great amount of such materials from the raw coconut husk yields the TCH which is mainly cellulose with rougher surface, increased hydrophilicity and high porosity. Hence, at a particular age of curing, the amount of water absorbed by block samples in which sand component is partially replaced with the TCH is greater compared to the case of blocks made with the UCH material of same proportion. In other words, the alkaline treatment employed changes the morphology of the raw coconut husk and increases water absorption capability of the resulting TCH. This finding resonates with the submission of Faola et al., (2013). Statistically, assessing the water absorption test results at 0.05 level of significance using one-way analysis of variance between the use of the UCH and application of the TCH gives calculated F-values of 5.35 and 5.34 for 7 days and 28 days curing periods respectively. When comparing the critical F-value (5.32) with the calculated values obtained, it shows that a significant difference is established in the instant case.

In this work, the highest recorded mean value of percentage water absorption $(6.29 \pm 0.05) \%$ is observed to be about ( $5.17 \pm 0.05) \%$ less than the maximum value of $12 \%$ stipulated in NIS 87 , (2007). This shows that with up to $40 \%$ content of the UCH or TCH, solid core sandcrete blocks can be produced to have water absorption capacity that satisfies the standard requirement for building design. The trend in the variation of percentage water absorption with the proportion 
of coconut husk used to replace sand in the block samples is illustrated in figure 4. Observably, there is increase in the percentage water absorption with added proportion of either the UCH or $\mathrm{TCH}$ at both curing ages. This indicates that the coconut husk materials (untreated and treated) have greater water absorption tendency than the sand used in producing the block samples. At the age of 28 days, the plots show that the percentage water absorption of the block samples tends to stabilise when $10 \%$ to $20 \%$ of the sand content is replaced with the UCH. In the case of using the TCH, such behaviour is exhibited between $20 \%$ and $30 \%$ levels of partial sand replacement.

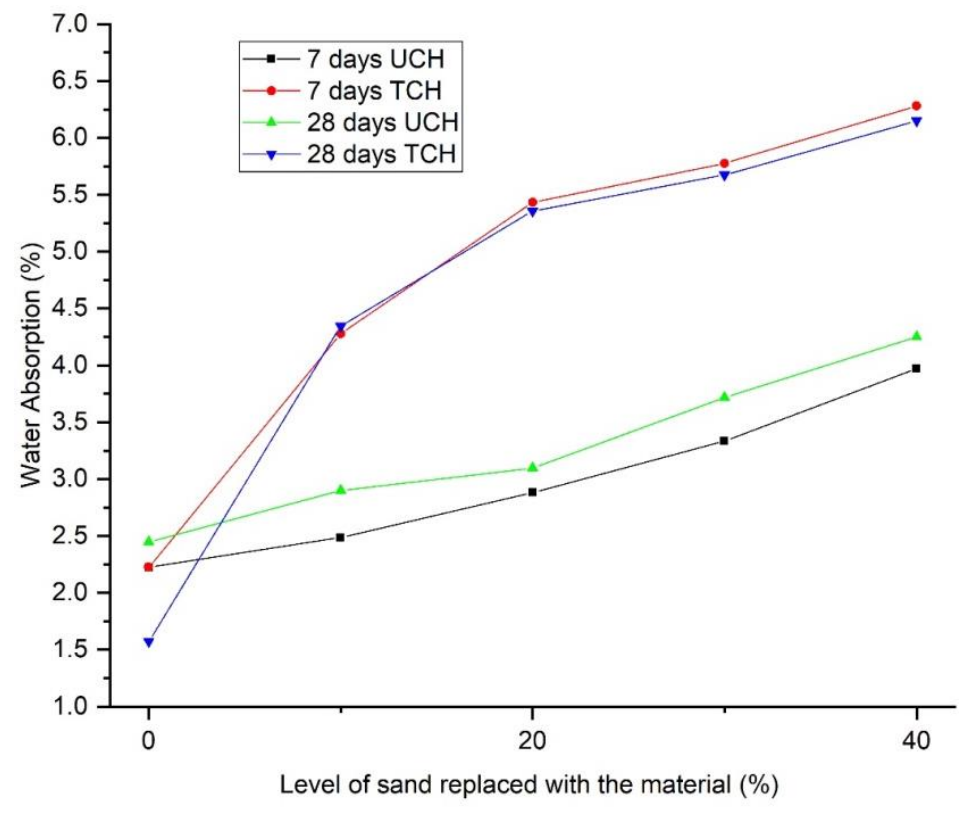

Fig. 4. Variation of water absorption with coconut husk level in the block samples

Furthermore, the results presented reflect that the compressive strength of the block samples vary in consonance with the age of curing. This observation is fully supported by the report of Dashan and Kamang (1999). The possibility of it may be due to hydration since such chemical reaction leads to reduction in the porosity of cement used while the evaporable water ensures gain in the strength of the block samples. When comparing the UCH with the TCH in terms of their degree of influence as sand partial replacement materials in the block samples, the results obtained show an appreciable improvement with the use of the TCH at either age of curing. As a matter of fact, the presence of hydroxyl and polar groups in the UCH leads to weak interfacial bonding, which implies ease of crushing of block samples containing it (that is, the UCH).

On the contrary, the chemical treatment with sodium hydroxide solution employed to produce the TCH from raw coconut husk increases the surface adhesion and enables the TCH to have a greater bonding ability than the UCH. Based on the results recorded, it can be argued that when up to $20 \%$ content of the UCH or $30 \%$ component of the TCH is used, the block samples produced meet the minimum requirement of $2.5 \mathrm{~N} / \mathrm{mm}^{2}$ according to NIS 87 , (2007) for nonload bearing walls. However, since $3.5 \mathrm{~N} / \mathrm{mm}^{2}$ is also the minimum value recommended for load bearing walls, it is important to mention here that in addition to block samples made with $0 \%$ content of coconut husk, only those containing up to $10 \%$ sand partial replacement with the UCH and cured for 28 days or others similarly developed with at most $20 \%$ content of the TCH and cured for at least 7 days can give satisfactory performance as well (even though they contain light weight aggregates). The graphical depiction of decrease in compressive strength of the block samples as the proportion of the UCH or TCH increases (figure 5) confirms that bulk density has influence on the compressive strength of the blocks. There is no doubt that after the chemical treatment process, the number of dead air cells present in UCH is very much reduced in 
the TCH. Eventually, cell wall densification is increased with improvement of adhesion in the $\mathrm{TCH}$, thereby increasing the bulk density and compressive strength of the block samples in which it is used. But due to the refractory nature of coconut husk, adding more quantity of the $\mathrm{UCH}$ or TCH brings about decrease in compressive strength. By testing the results obtained at 0.05 level of significance using Pearson's product moment correlation, the coefficients reveal that there exists a very high positive relationship between bulk density and compressive strength of the block samples.

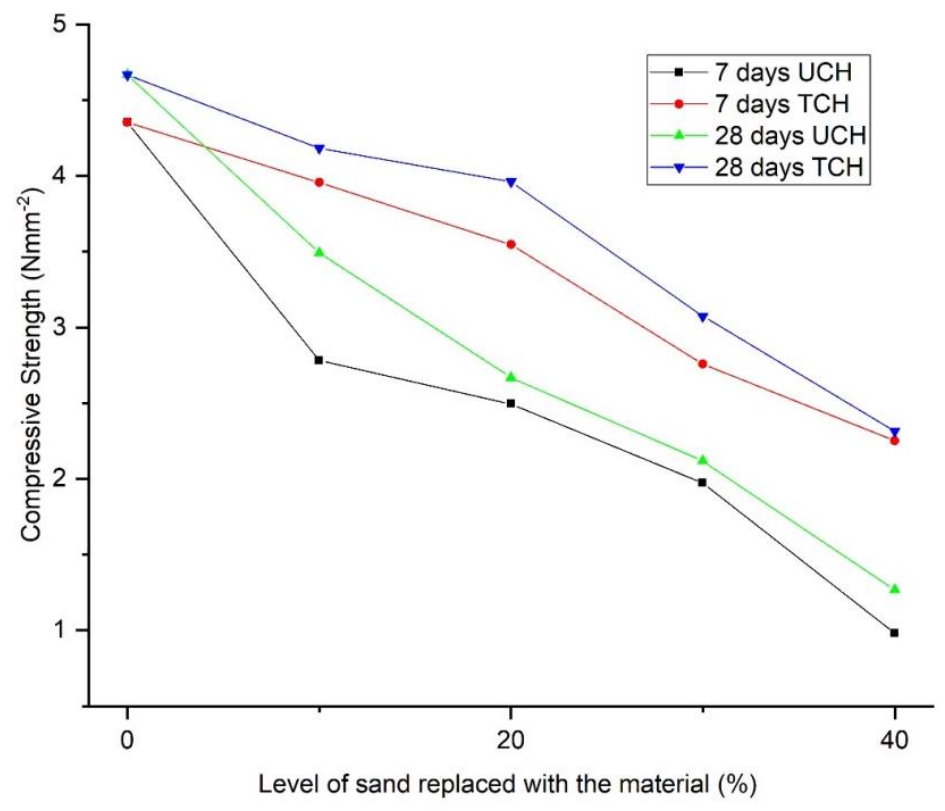

Fig. 5. Variation of compressive strength with coconut husk level in the block samples

\section{Conclusion}

Untreated and treated coconut husks were separately utilised at the same proportions to partially replace sand in the solid core sandcrete block samples produced and tested at curing periods of 7 days and 28 days in this work. At both ages of the block samples, the experimental verdicts showed increase in percentage water absorption but decrease in bulk density and compressive strength with increasing proportions of either the untreated or treated coconut husks used. Also, for a particular age of curing, all the properties examined were found to be of higher value in the case of block samples containing the treated coconut husk compared to their counterparts with untreated coconut husk component. Based on the requirements stipulated by Nigerian Industrial Standard and British Standard institute for solid core sandcrete blocks, it was observed that the block samples produced by partially replacing sand content with up to $40 \%$ of coconut husk (either untreated or treated) and cured for at least 7 days are lightweight with water absorption capacity suitable for non-load bearing walls. However, it was evident that if emphasis is solely on compressive strength, then sand replacement with $20 \%$ of untreated coconut husk or $30 \%$ of treated coconut husk should be the ultimate choice for satisfactory performance of the developed sandcrete blocks in building designs.

\section{References}

Afolayan, J. O., Oriola, F. O. P., Moses, G., \& Sani, J. E. (2017). Investigating the effect of eggshell ash on the properties of sandcrete block. International Journal of Civil Engineering, Construction and Estate Management, 5(3), $43-54$.

Akinpelu, A.T. \& Adekanmbi, J. (2017). Comparing compressive strength of sandcrete blocks made with sand from different sources. Researchjournali's Journal of Civil Engineering, 3(4), 2 - 6. 
Akinyele, J. 0., \& Toriola, I. O. (2018). The effect of crushed plastics waste on the structural properties of sandcrete blocks. African Journal of Science, Technology, Innovation and Development, 10(6), 709-713.

Ali, N., Din, N., Khalid, F. S., Shahidan, S., Abdullah, S. R., Samad, A. A. A., \& Mohamad, N. (2017). Compressive strength and initial water absorption rate for cement brick containing high-density polyethylene (HDPE) as a substitutional material for sand. Series: Materials Science and Engineering, 271, 012083.

ASTM C136/136M, (2019). Standard Test Method for sieve analysis of fine and coarse aggregates, ASTM International, West Conshohocken, Pennsylvania.

Baiden, B. K., \& Tuuli, M. M. (2004). Impact of quality control practices in sandcrete blocks production. Journal of Architectural Engineering, 10(2), 53-60.

Bolivar-Telleria, M., Turbay, C., Favarato, L., Carneiro, T., de Biasi, R. S., Fernandes, A. A. R., Santos, A.M.C. \& Fernandes, P. (2018). Second-generation bioethanol from coconut husk. BioMed research international, Article ID 4916497, 20 pages.

BS 2028, (1975). British Standard Institute, Precast concrete blocks. London.

BS 882, (1992). British Standard Institutions, Specification for aggregate from natural sources for concrete. London.

Building Code, (2006). Federal Republic of Nigeria: National Building Code, First edition.

Burton, J. (2018). The World leaders in coconut production, www.worldatlas.com Last accessed: April 19, 2018.

Campbell-Falck, D., Thomas, T., Falck, T. M., Tutuo, N., \& Clem, K. (2000). The intravenous use of coconut water. The American journal of emergency medicine, 18(1), 108-111.

Dashan, I.I. \& Kamang, E.E.J. (1999). Some characteristics of RHA/OPC concretes: A preliminary Assessment. Nigerian Journal of Construction Technology and Management, 2(1), 22 - 28.

Etuk, S. E., Akpabio, L. E., \& Akpabio, K. E. (2005). Determination of thermal properties of Cocos Nucifera trunk for predicting temperature variation with its thickness. The Arabian journal for science and Engineering, 30(1A), 121-126.

Faola, A. E., Oladele, I. O., Adewuyi, B. O., \& Oluwabunmi, K. E. (2013). Effect of chemical treatment on water absorption capability of polyester composite reinforced with particulate agro-fibres. Chemistry and Materials Research, 3(13), 106-112.

Harini, S. (2010). Coconut Water. American Society for Nutrition. https://nutrition.org/coconut-water/ Last accessed: June 21, 2020.

Korjakins, A. Śahmenko, G. Bajare, D. Gaidukovs, S. \& Pizele, D. (2009). Producing of concrete by using a dolomite waste as an alternative filler. Ěpitǒanyag-Journal of Silicate Based and Composite Materials, 61(2), $44-47$.

NIS 87, (2007). Nigerian Industrial Standard: standard for sandcrete blocks, Standard Organisation of Nigeria, Lagos.

Ojo, O.J. (2015). Post project review of Lumber used for construction of building projects in Osun State, Nigeria. International Journal of Scientific Research and Innovation Technology, 2(4), 39 - 49.

Oladeji, O. S., \& Awos, O. A. (2013). Assessment of Materials and Process Variables on Regulatory Compliance of Sandcrete Blocks: A Case Study of Ogbomoso, Nigeria. International Journal of Engineering Research and Applications, 3(6), 793-799.

Omoregie, A. (2012). Impact of vibration time on compressive strength of hardened sandcrete building blocks. Buildings, 2(2), 153-172.

Prades, A., Dornier, M., Diop, N., \& Pain, J. P. (2012). Coconut water uses, composition and properties: a review. Fruits, 67(2), 87-107. 
Robert, U. W., Etuk, S. E., Umoren, G. P., \& Agbasi, O. E. (2019). Assessment of Thermal and Mechanical Properties of Composite Board Produced from Coconut (Cocos nucifera) Husks, Waste Newspapers, and Cassava Starch. International Journal of Thermophysics, 40(9), 83.

Zafar, S. (2020). Uses of coconut wastes, www.bioenergyconsult.com Last accessed: January 18, 2020. 